\title{
Mikoriza ve Fungusit Uygulamalarının Domates Bitkisinin Bazı Büyüme ve Gelişim Parametreleri Üzerine Etkisi
}

\author{
Tuğba ÖZBUCAK ${ }^{1 *}$, Döndü KABUL ${ }^{2}$, Öznur ERGEN AKÇİN ${ }^{3}$
}

Geliş / Received: 07/04/2020

Revize / Revised: 11/06/2020

Kabul / Accepted: 11/06/2020

ÖZ

$\mathrm{Bu}$ çalışmada mikoriza olan ve olmayan ortamlarda büyütülen domates bitkilerine uygulanan farklı fungusit dozlarının bitkinin kök, gövde uzunluğu, yaprak kuru ve yaş ağırlığı, spesifik yaprak alanı (SLA), yaprak kütle ağırlığı (LMA) üzerindeki etkileri incelenmiştir. Fungusit dozları çiftçiye önerilen tarla dozu (D), önerilenin yarısı doz (D/2) ve önerilenin iki katı doz (D*2) şeklinde uygulanmıştır. Mikorizalı ortamda büyütülen bitkilerin bütün fungusit dozlarında kök ve gövde uzunlukları ile yaprak yaş ve kuru ağırlık değerleri mikorizasız olanlara göre daha yüksek bulunmuştur. Bununla beraber, istatistiki analiz sonuçlarına göre, sadece gövde uzunluğu $(\mathrm{P}<0.01)$ ve yaprak kuru ağırlığı $(\mathrm{P}<0.05)$ değerlerinin istatistiki olarak önemli olduğu belirlenmiştir.

\footnotetext{
1*Sorumlu yazar iletişim: tsiozbucak@hotmail.com (https://orcid.org/0000-0002-4784-3537) Moleküler Biyoloji ve Genetik Bölümü, Ordu Üniversitesi Fen-Edebiyat Fakültesi, Ordu, Türkiye 2İletişim: fth.52.fk@gmail.com (https://orcid.org/0000-0002-6555-8107) Penpe İzzet Şahin Güzel Sanatlar Lisesi, Ordu, Türkiye 3̇̉letişim: oakcin@gmail.com (https://orcid.org/0000-0002-6875-6045) Moleküler Biyoloji ve Genetik Bölümü, Ordu Üniversitesi Fen-Edebiyat Fakültesi, Ordu, Türkiye
} 


\title{
Effect of Mycorrhiza and Fungicide Applications on Some Growth and Development Parameters of Tomatoes
}

\begin{abstract}
In this study, the effect of different fungicide doses applied on tomato plants grown in mycorrhiza and nonmycorrhiza environments on a plant root, stem length, leaf dry and wet weight, specific leaf area (SLA), leaf mass area (LMA) were investigated. Fungicide doses were applied to the farmers as recommended field dose (D), half of the recommended $(\mathrm{D} / 2)$, and two-fold recommended $(\mathrm{D} * 2)$. The lengths of root and stem and wet and dry weights of leaf in tomato plant grown in all of the fungicide doses in mycorrhiza environment were found higher compared to non-mycorrhiza environments. However, according to the results of statistical analyses, only stem length $(\mathrm{P}<0.01)$ and leaf dry weight $(\mathrm{P}<0.05)$ values were determined to be statistically significant.
\end{abstract}

Keywords: Mycorrhiza, Tomato (Solanum lycopersicum L.), Fungicide 


\section{I.GIRIŞ̧}

Mikorizaların bitkiler ile mikroorganizmalar arasında görülen önemli simbiyotik ilişkilerden birisi olduğu, bitkilerin yeryüzündeki dağılışında önemli rol oynadıkları düşünülmektedir [1,2,3]. Bitkilerin büyük bir kısmında mikorizal oluşum görülmekle beraber, Glomales ordosunun Zygomecetes arbüsküler tipi tarım ürünlerinde en sık bulunanıdır [4]. Arbüsküler mikorizal funguslar, tek ve çok yıllık bitkilerin köklerine kolayca enfekte olabilme yeteneklerinden dolayı farklı konukçu türleri üzerinde kültüre alınabilirler [5]. Arbüsküler mikorizal (AM) funguslar bitkinin büyüme ve gelişmesini uyarmasının yanında, biyotik ve abiyotik stres faktörlerine karşı toleransını arttırmasına da katkı sağlarlar [6]. Bununla beraber AM fungusların besin elementi alınımı, transferi, su ekonomisi ve klorofil içeriği gibi önemli biyokimyasal ve fizyolojik özellikler üzerinde de önemli rol oynadığı bildirilmektedir [7,8].

Son yıllarda yanlış tarımsal uygulamalar sonucu bitki kökleri ile mantar miselleri arasında karşılıklı fayda sağlayan bu ilişkinin bozulması toprak özellikleri ve ekosistem süreçlerini olumsuz etkilemektedir. Mikorizal mantarları azalmış bir komünitede, mikoriza özelliği taşımayan yabani ot türleri artmakta, besin elementi döngüsü bozulmaktadır. Bununla beraber tarımda kontrolsüz ve bilinçsiz pestisit kullanımından kaynaklan yanlış uygulamalar bulunmaktadır. Kullanılan tüm pestisitler hem doğada hem de canlı organizmalarda az ya da çok farklı etkiye sahiptirler $[9,10]$. Bu ve benzeri nedenlerden dolayı tarım toprakları çoğu zaman yeterli sayı ve etkinlikte mikoriza bulunduramamaktadır. Doğal mekanizmaların etkin olmadığı, yeterince organik gübrelemenin yapılamadığı ortamlarda optimum ürün yetiştiriciliği için tarım topraklarına mikoriza ilave edilmesi önemli olmaktadır. Yapılan bazı çalışmalar ile mikorizal mantarların bitki hastalık ve zararları ile mücadelede, toprak sorunlarına karşı dayanıklılık geliştirmekte ve bitki büyümesine katkı sağlamada yaygın bir şekilde kullanıldığı bildirilmektedir $[11,12,13,14,15,16,2,8]$.

Bu çalışmanın amacı, Arbusküler Mikorizal Fungus (Glomus fasciculatum, Glomus intraradices, Glomus mosseae) uygulanmış ve uygulanmamış ortamlarda büyütülen domates bitkisinin bazı morfolojik parametreleri üzerinde ticari bir fungusitin farklı dozlarının etkilerini karşılaştırmaktır. Mikorizal ilişkilerin bitkinin büyüme ve gelişmesi, besin elementi içeriği, bitkiye sağladığı avantajlar ile fungusit kullanımının bitki üzerindeki etkisini ortaya koyan ayrı ayrı çalışmalar mevcuttur. Yapılan çalışmada mikorizalı ve mikorizasız bitkilerde bazı büyüme ve gelişme parametreleri üzerinde fungusit kullanımının meydana getirdiği etkiler karşılaş̧ırılmaya çalışılmıştır. Kontrolsüz ve bilinçsiz kullanım sonucu artan fungusit tüketimi bitkilerde ve besin zinciri yoluyla da insan dâhil diğer canlılarda birtakım zararlara yol açmaktadır. Bitkiye pek çok avantaj sağlayan mikorizanın bitkideki etkilerini incelemeye çalışmak bu araştırmanın öncelikli amaçlarından birisidir. Bu amaçla ülkemizde ve dünyada en çok üretilen ve tüketilen sebzelerden biri olan ve ihracatı sırasında pestisit kalıntısı sorunları yaşanabilen domates seçilmiştir.

\section{MATERYAL VE METOT}

Çalışmada ticari olarak satın alınan domates tohumları, Glomus fasciculatum, Glomus intraradices, Glomus mosseae karışımı mikoriza ile Propineb etken maddeli bir fungusit kullanılmıştır. Çalışmanın başlangıcında sterilize edilen domates tohumlarının yarısı mikoriza ile inokule edilmiştir. 2:1:1 oranında torf: perlit: toprak karışımı olan plastik kaplara ekilen tohumlar $23,5^{\circ} \mathrm{C}, \% 60$ nem şartlarında gece gündüz periyoduna ayarlanmış iklim dolabında yaklaşık bir hafta çimlendirilmiştir. Laboratuvarda bir süre daha bekletilen fideler saksılara alınarak sera ortamında büyümeye bırakılmıştır.

Denemede toplam 24 saksının 12 tanesi mikoriza ile inoküle olanlardan diğer 12 tanesi ise mikoriza olmayanlardan oluşmaktadır. Yaklaşık bir ay sonra sera ortamına alınan saksılardan kontrol grubu dışındakilere püskürtücü yardımıyla 7 gün ara ile $5 \mathrm{kez}$ çiftçiye önerilen tarla dozu (D), önerilenin yarısı (D/2) ve önerilenin iki katı (D*2) olacak şekilde fungusit uygulanmıştır. Çalışma üç tekerrürlü olarak yürütülmüsşür.

Yaprakların yaş ve kuru ağılıklarının belirlenmesi için her deneme grubundan alınan yapraklar tartılarak yaş ağırlıkları hassas terazi yardımı ile ölçülmüştür. Ölçümü yapılan yaprak örnekleri $60^{\circ} \mathrm{C}$ ' de 72 saat kurutulup, hassas bir terazi yardımıyla bitkilerin kuru ağırlıkları kaydedilmiştir. 


\begin{tabular}{|c|c|c|}
\hline & $\begin{array}{l}\text { BŞEÜ Fen Bilimleri Dergisi } \\
7(1), 529-543,2020\end{array}$ & $\begin{array}{l}\text { BSEU Journal of Science } \\
\text { DOI: } 10.35193 / \text { bseufbd.716195 }\end{array}$ \\
\hline IVERSI & & 58-7575 (http://dergipark.gov.tr/bseufbd) \\
\hline
\end{tabular}

Hasat döneminin başlangıcında (yaklaşık 3,5 ay sonra) domates meyveleri alındıktan sonra kök ve gövde uzunluğunun ölçülmesi için bitkiler saksıdan alınmadan önce toprak hizasından başlayarak cetvel yardımıyla ana gövde boyları, saksılardan söküldükten sonra ise kök boyları ölçülmüştür.

Bitkinin vejetatif döneminde toplanan yaprak numunelerin sapları kesilip birkaç gün preslendikten sonra spesifik yaprak alanı (SLA) değerleri planimetre ile ölçülmüştür. Spesifik yaprak alanı (SLA) ve yaprak kütle ağırlı̆̆ı (LMA) aşağıdaki formüller yardımıyla hesaplanmıştır.

$\mathrm{SLA}=\sum$ alan$/ \sum$ ağırlık, SLA =Ortalama spesifik yaprak alanı $\left(\mathrm{dm}^{2} / \mathrm{g}\right)$

Alan=Toplam yaprak alanı, Ağırlık=Toplam yaprak kuru ağırlık (g)

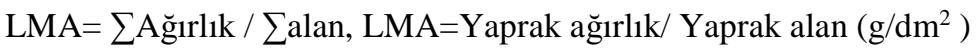

Ağırlık = Toplam yaprak kuru ağırlık (g), Alan =Toplam yaprak alanı $\left(\mathrm{dm}^{2}\right)$

\section{BULGULAR}

\section{A. Kök Uzunluğu (cm)}

Bitki kök uzunluğu ile ilgili morfolojik sonuçlar Şekil 1 ve Tablo 1'de verilmiştir. Sonuçlara bakıldığında, Kontrol, D, D/2 ve D*2 fungusit dozlarında mikorizalı bitkilerin köklerinin daha uzun ve daha yoğun olduğu görülmektedir. Bitkinin kök uzunluğuna $(\mathrm{cm})$ ait istatistiki analiz sonuçlarına göre anlamlı bir farklılık olmadığı görülmektedir ( $\mathrm{P}>0.05)$ (Tablo 1). Ancak kök uzunluğu ile ilgili ortalama değerlere bakıldığında mikorizalı olan bitkilerin kök uzunluğunun mikorizasız olan bitkilere göre daha yüksek olduğu tespit edilmiştir. Mikorizalı olanlarda fungusit dozu artışına bağlı olarak azalma olduğu görülmektedir. Kök uzunluğu bakımından Kontrol grubunda, D, D/2 ve D*2 dozlarında mikorizalı>mikorizasız şeklindedir.
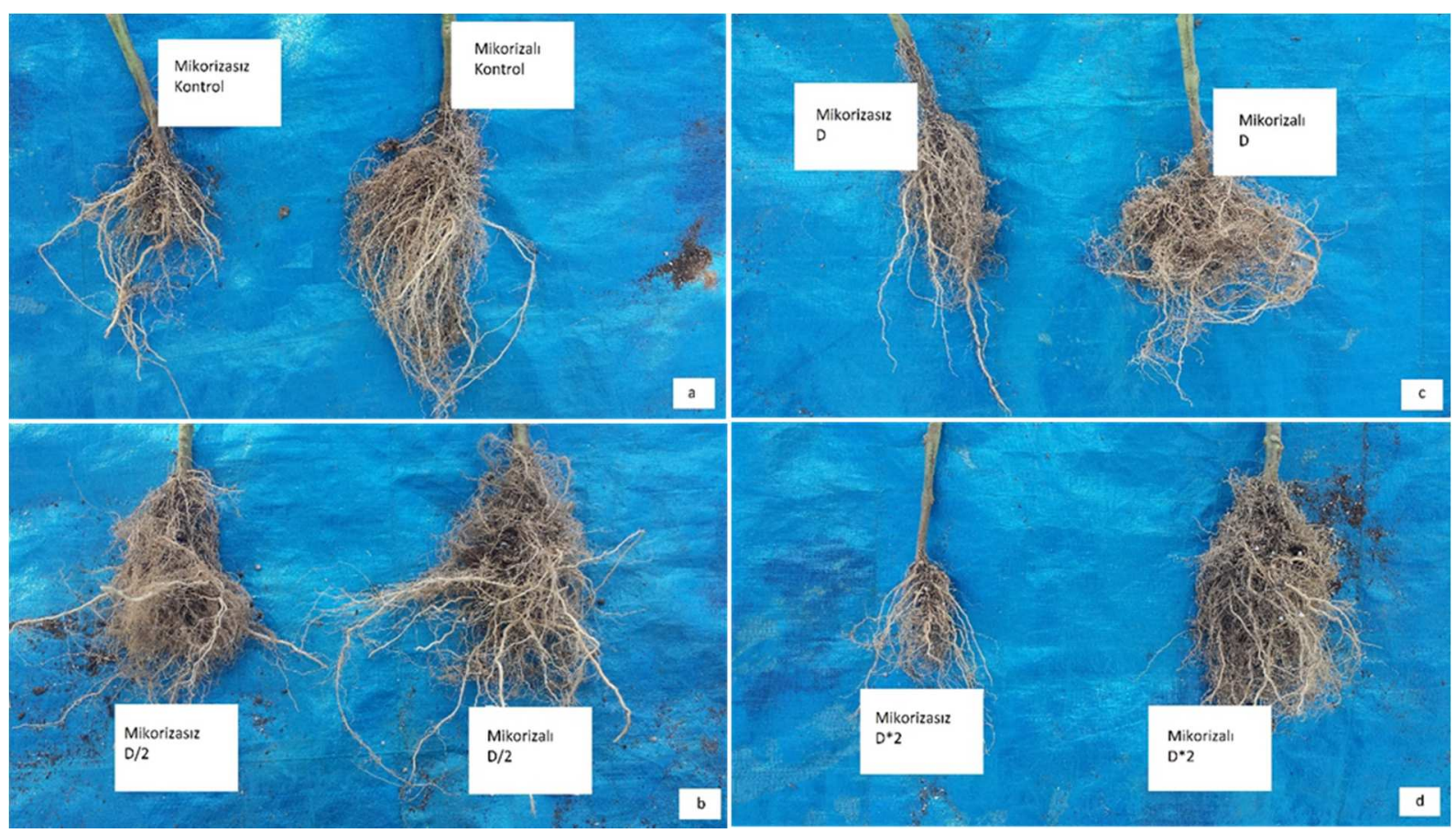

Şekil 1. Kök uzunluklarının karşılaştırılması (a: Kontrol grubu kök uzunluğu, b: D/2 dozu kök uzunluğu, c: D dozu kök uzunluğu, d: D*2 dozu kök uzunluğu) 


\begin{tabular}{|c|c|c|}
\hline & $\begin{array}{l}\text { BŞEÜ Fen Bilimleri Dergisi } \\
7(1), 529-543,2020\end{array}$ & $\begin{array}{l}\text { BSEU Journal of Science } \\
\text { DOI: } 10.35193 / \text { bseufbd.716195 }\end{array}$ \\
\hline UERS I & & 58-7575 (http://dergipark.gov.tr/bseufbd) \\
\hline
\end{tabular}

\section{B. Gövde uzunluğu $(\mathrm{cm})$}

Şekil 2 ve Tablo 2'de bitki gövde uzunluğu ile ilgili morfolojik sonuçlar verilmiştir. Sonuçlara göre Kontrol, D, D/2 ve D*2 fungusit dozlarında mikorizalı bitkilerin gövdelerinin daha uzun olduğu görülmektedir. Gövde uzunluğuna $(\mathrm{cm})$ ait tanıtıcı istatistik değerleri, varyans analizi ve Tukey testi analizi sonucunda mikoriza*doz interaksiyonunun istatistik olarak önemli olmadığı görülmektedir $(\mathrm{P}>0.05)$. Aynı şekilde mikoriza olup olmaması arasında da istatistikî olarak önemli bir fark bulunmamıştır $(\mathrm{P}>0.05)$. Ancak gövde uzunluğu ile ilgili ortalama değerlere bakıldığında mikorizalı olan bitkilerin gövde uzunluğunun mikorizasız olan bitkilere göre daha yüksek olduğu tespit edilmiştir. Gövde uzunluğu bakımından Kontrol grubunda, D ve D*2 dozunda mikorizalı>mikorizasız şeklindedir. D/2 dozunda ise mikorizalı<mikorizasız şeklindedir. Fungusit dozları arasındaki farklılık ise istatistik olarak anlamlı bulunmuştur $(\mathrm{P}<0.01)$. Hangi dozlar arasında farklılık olduğunun belirlenmesi amacıyla yapılan Tukey testi sonuçları incelendiğinde, bitkideki gövde uzunluğu D/2, Kontrol ve D*2 dozlarına göre daha yüksek bulunmuştur $(\mathrm{P}<0.05)$. Ancak $\mathrm{D} / 2$ ve $\mathrm{D}$ dozları arasındaki fark istatistikî olarak önemli değildir ( $>>0.05)$ (Tablo 2).

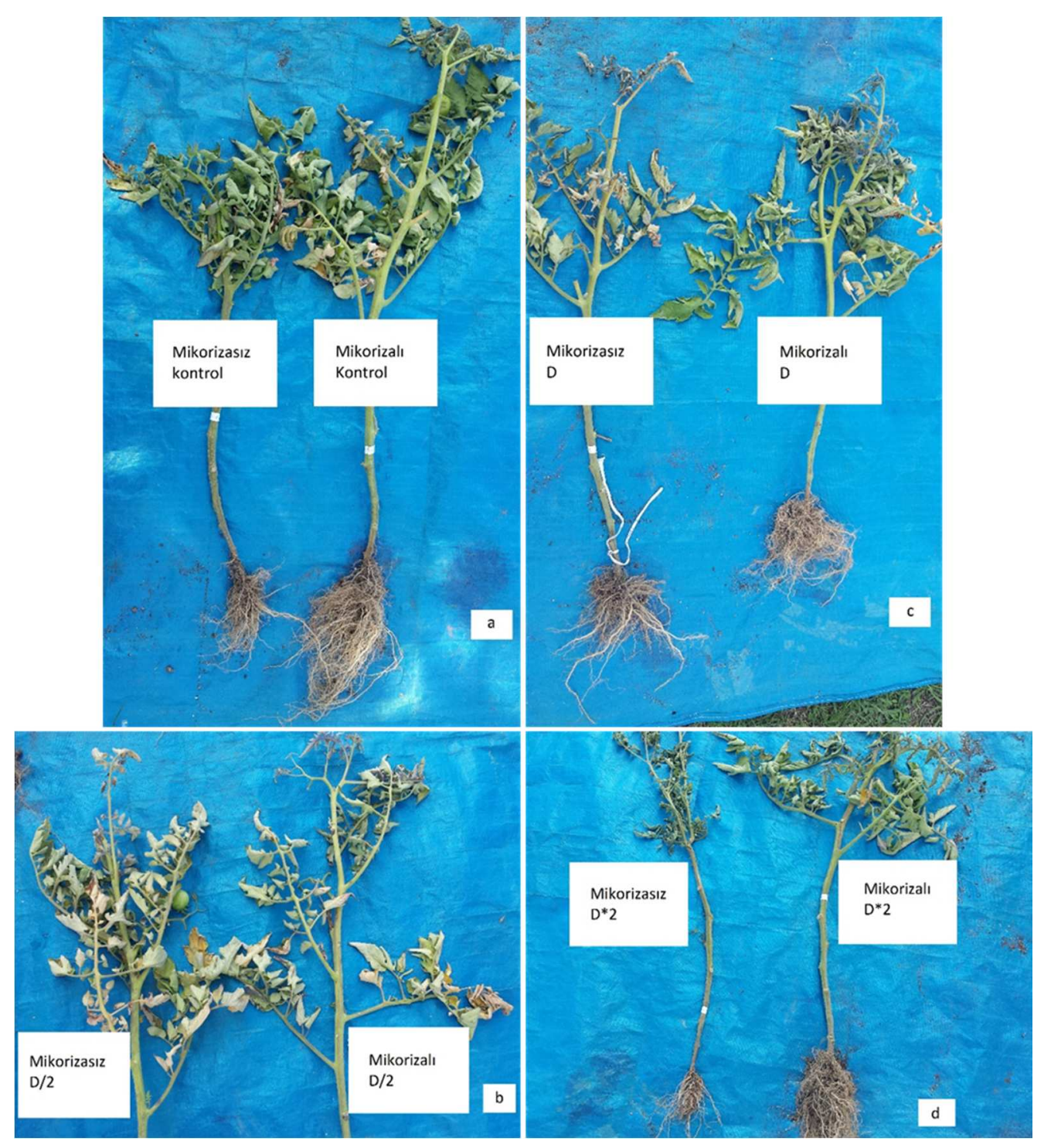

Şekil 2. Gövde uzunluklarının karşılaştırılması (a: Kontrol grubu gövde uzunluğu b: D/2 dozu gövde uzunluğu, c: D dozu gövde uzunluğu, d: D*2 dozu gövde uzunluğu) 


\section{Yaprak yaş ăğırlığl ( $g$ )}

Yaprak yaş ağırlığına (g) ait istatistiki analizi sonuçları Tablo 3'de verilmiştir. Tabloya göre varyans analizi sonucunda farklılıkların istatistik olarak önemli olmadığı görülmektedir $(\mathrm{P}>0.05)$. Yaprak yaş ağırlığı ile ilgili ortalama değerlere bakıldığında mikorizalı olan bitkilerin yaprak yaş ağırlığının mikorizasız olan bitkilere göre daha yüksek olduğu görülmektedir. Yaprak yaş ağırlığı bakımından Kontrol grubunda, D, D/2 ve D*2 dozlarında mikorizalı >mikorizasız şeklindedir.

\section{Yaprak kuru ăgırlı̆̆l $(g)$}

Tablo 4'de yaprak kuru ağırlığına (g) ait tanıtıcı istatistik değerleri ve varyans analizi sonuçları verilmiştir. Çizelge 4.7 incelendiğinde, varyans analizi sonucunda mikoriza*doz interaksiyonunun istatistiki olarak önemli olmadığı görülmektedir ( $\mathrm{P}>0.05)$. Aynı şekilde fungusit dozları arasındaki farklılık da istatistik olarak önemli bulunmamıştır $(\mathrm{P}>0.05)$. Mikorizalı bitkilerin yaprak kuru ağırlığının mikorizasız olanların yaprak kuru ağırlığından önemli derecede yüksek olduğu görülmektedir $(\mathrm{P}<0.05)$.

\section{E. Spesifik yaprak alanı (SLA dm2/g)}

Spesifik yaprak alanına ( $\left.\mathrm{dm}^{2} / \mathrm{g}\right)$ ait istatistik analiz sonuçları Tablo 5'de verilmiştir. Tabloya bakıldığında varyans analizi sonucunda farklılıkların istatistiki olarak önemli olmadığı görülmektedir $(\mathrm{P}>0.05)$. Ancak spesifik yaprak alanı ile ilgili ortalama değerlere bakıldığında Kontrol grubu ve D/2 dozunda mikorizalı>mikorizasız şeklindedir. D ve D*2 dozunda ise mikorizalı<mikorizasız şeklindedir.

\section{F. Yaprak kütle ăgırlı̆̆l (LMA g/dm²)}

Tablo 6'da yaprak kütle ağırlığına ait istatistiki analiz sonuçları verilmiştir. Sonuçlar incelendiğinde varyans analizi sonucunda hiçbir farklılı̆̆ın istatistik olarak önemli olmadığı görülmektedir (P>0.05). Ancak yaprak kütle ağırlığı ile ilgili ortalama değerlere bakıldığında Kontrol ve D/2 dozunda mikorizalı<mikorizasız şeklinde iken $\mathrm{D}$ ve $\mathrm{D} * 2$ dozlarında mikorizalı >mikorizasız şeklindedir

\section{TARTIŞMA VE SONUÇ}

Bu çalışmada mikoriza inoküle edilen ve edilmeyen ortamlarda büyütülen domates bitkilerine uygulanan farklı dozlardaki fungusit uygulamalarının kök, gövde, yaprak gibi vejetatif kısımları üzerindeki etkisi belirlenmeye çalışılmıştır. Çünkü bu özellikler bitkinin bulunduğu ortamda meydana gelen değişikliklere karşı duyarlı olan bitkinin önemli ekolojik indikatörler özellikleridir [17]. Morfolojik ölçümlere ait sonuçlara bakıldığında kök uzunluğu ve yaprak yaş ağırlığı değerlerinin istatistiki olarak önemli olmadığı, gövde uzunluğu ve yaprak kuru ağırlığı değerlerinin istatistiki olarak önemli olduğu belirlenmiştir. Bitki kök uzunluğu ile ilgili istatistiksel olarak önemli bir fark olmamakla beraber mikoriza inoküle olan bitkilerin kontrol, D/2, D, D*2 dozlarının kök uzunluklarının, mikoriza olmayan bitkilerin aynı dozlarına göre daha uzun ve sık olduğu görülmektedir. [18] tarafından yapılan bir çalışmada AMF uygulanmış bitkilerin uygulanmayanlara göre istatistiksel olarak önemli çıkmamış olanlarda dahi iyi gelişim gösterdiği belirlenmiştir.

Bitki köklerinin mikoriza ile enfekte olduğunda daha fazla su ve besin elementi alabildiği bildirilmektedir [19, 6, 8]. [9] tarafından yapılan bir çalışmada mikoriza ile aşılanan tüm bitkilerin vejetatif gelişme dönemi sonrasında daha iyi bir kök sistemine sahip oldukları belirtilmiştir. Mikorizal fungusların bitki kökleri tarafından alımı yavaş olan besin elementlerini özellikle de fosforun alınımını önemli derecede arttırdığı yapılan bazı çalışmalar ile belirlenmiştir [9, 20, 21]. Mikoriza hifleri çok ince yapısı ile köklerin giremediği ince porlara girerek su ve besin elementlerinden yararlanabilmektedir [22]. Yapılan bu çalışmada da kök gelişiminde olumlu durumun diğer çalışmalar ile paralellik gösterdiği görülmektedir. Bununla beraber, bitki kök uzunluğu değerlerinin fungusit uygulanan örneklerde doz arttıkça kontrole göre azaldığı görülmektedir. Bu durum fungusitlerin bitkinin büyüme ve gelişimi üzerine yaptığı olumsuz etkilerden kaynaklanmış olabilir.

Bitki gövde uzunluğuna ait sonuçlar bitkilerin mikorizalı olup olmaması ve mikoriza-doz interaksiyonu açısından istatistiki olarak önemli bulunmamıştır. Ancak gövde uzunluğu ile ilgili ortalama değerlere bakıldığında mikorizalı bitkilerin gövde uzunluğunun mikorizasız olan bitkilere göre daha fazla olduğu tespit edilmiştir. Bununla beraber, fungusit dozları arasındaki farklılık ise istatistik olarak önemli bulunmuştur. [23] tarafından yapılan bir sera denemesinde G. mosseae'nin domateste bitkinin boy, sürgün kuru ağırlığı ve çiçek miktarını 
kontrol bitkisine göre önemli ölçüde arttırdığı tespit edilmiştir. AMF uygulamalarının kök, gövde ve vejetatif gelişimi arttırdığ bildirilmiştir [18, 24].

Yapılan çalışmada uygulanan bütün fungusit dozlarında mikorizalı bitkilerin yaş ağırlığının mikorizasızlardan daha yüksek olduğu, ancak sonuçların istatistiki olarak önemli olmadığı tespit edilmiştir. Aynı zamanda fungusit uygulanan örneklerin yaş ağırlığı kontrole göre azalmıştır. [25] tarafından yapılan çalışmada mikorizanın biber bitkisinin yaş ve kuru ağırlıkları üzerine olan etkisini belirlemek amacıyla yaptıkları çalışmada, mikoriza uygulanan biber bitkilerinin yaş ve kuru ağırlıklarının arttığı tespit edilmiştir.

Yaprak kuru ağırlığı değerlerine bakıldığında mikoriza-doz etkileşiminin ve fungusit dozlarının istatistiki olarak önemli olmadığı görülmektedir. Ancak mikorizalı bitkilerin yaprak kuru ağırlığının mikorizasızların yaprak kuru ağırlığından daha yüksek olduğu ve istatistiki olarak önemli olduğu görülmektedir. Bu durum literatürdeki diğer çalışmalarla paralellik göstermektedir. Mikorizaların oluşturduğu ince hifler bitki köklerinin daha derine ulaşmasını, daha fazla yüzey alanı oluşturmasını sağlayarak köklerin temas yüzeyini arttırmaktadır. Mikoriza bitki köklerini enfekte ettiği zaman bitki fungusun oluşturduğu hifleri kökün bir parçasıymış gibi kullanarak daha fazla besin elementi ve su almaktadır [25, 17]. Bu nedenle mikoriza uygulaması bitkide kuru madde miktarını arttırmaktadır [26]. [27] tarafından yapılan bir çalışmada da bizim çalışmamıza benzer olarak mikoriza ile enfekte olmuş bitkilerin kuru madde ağırlığının mikorizasız olanlardan daha yüksek olduğu belirlenmiştir. Yapılan diğer bir çalışmada da mikoriza aşılamanın patlıcan bitkisi üzerindeki etkileri incelenmiş, mikorizanın bitki gelişimi ve ona bağlı olarak da verimi artırdığı tespit edilmiştir [28].

Mevcut çalışmada spesifik yaprak alanı (SLA), yaprak kütle ağırlığı (LMA) ve yaprak yaş ağırlığı değerleri istatistiksel olarak önemli bulunmamıştır $(\mathrm{P}>0.05)$. SLA değerlerinin bitkilerin mikorizalı olup olmamasına göre istatistiksel açıdan anlamlı olmadığı fakat ortalama değerlere bakıldığında fungusit dozu arttıkça mikorizasız olan bitkilerde SLA değerlerinin daha büyük olduğu tespit edilmiştir. LMA ile SLA birbirinin tersi şeklinde formüle edildiği için LMA değerlerinde ise tam tersi bir durum görülmektedir. Mikorizasız bitkilerde fungusit dozuna bağlı olarak düşük SLA, yüksek LMA değerlerinin görülmesinin nedeni bitkilerin fotosentez oranlarındaki değişime bağlı olarak sentezledikleri organik madde miktarındaki değişim olabilir. Çünkü bitkiye fungusit uygulamasının yapıldığı yer bitkinin yaprakları olup, fungusitlerin fotosentetik pigment miktarlarını azaltarak fotosentezi olumsuz yönde etkilediği bildirilmektedir [29,30,31]. Mevcut çalışmada SLA değerlerinin düşük olmasının nedeni yaprakların büyüme aşamasında uygulanan fungusitin olumsuz etkisi olabilir. [32] tarafından yapılan bir çalışmada SLA ve LMA'nın besin elementlerinin etkili bir şekilde kullanılmasında ve hızlı biyokütle üretimi arasındaki değişimi dengelemede rol oynadığı bildirilmiştir. Çünkü SLA ve LMA kaynak kullanım stratejilerinin belirleyici özellikleridir ve çeşitli çevrelerdeki farklı bitki türleri için bu özellikleri değerlendirmek çok önemlidir.

Yapılan bu çalışma ile mikorizanın domates bitkisinin bazı büyüme ve gelişme parametreleri üzerinde fungusit uygulamasına rağmen olumlu etkileri olduğu belirlenmiştir. AMF'ler doğal ve tarımsal ekosistemlerin toprak rizosferinin önemli mikrobiyal simbiontlarından olup kök morfolojisindeki değişimleri uyarması, konukçu bitkinin besin durumunu geliştirmesi, patojen saldırılarında konukçunun toleransını arttırması ve bitki savunma mekanizmalarını aktive etmesi gibi etki mekanizmalarına sahiptirler [32]. Bitki büyüme ve gelişmesi, toprak verimliliği, bitki sağlığı, madde döngüsü gibi ekolojik süreçlerde önemli rol oynayan AMF'lerin bitkiye direnç ve koruma sağlayabileceği tespit edilmiştir. Bunun nedeni mikorizal birlikteliğin bitkinin fizyolojisi ve morfolojisi üzerinde yaptığı etkiler olabilir. [9] tarafından mikoriza uygulaması sonrasında yapılan fungusit uygulamasından mikorizanın etkilenmeyeceği bildirilmiştir. Mikoriza enfeksiyonunun bitki için zararlı elementleri ya bertaraf ederek ya da bünyesinde tutarak bitkiyi zararlı/toksik maddelerden koruyabileceği belirtilmiştir. Bu noktadan hareketle, saksı denemelerinden elde edilen bu başlangıç verilerinin bu konuda ileride yapılacak tarla denemeleri gibi daha kapsamlı çalışmalara ve literatüre 1şık tutacağı kanısındayız.

\section{TEŞEKKÜR}

Bu çalışma OrduÜniversitesi Bilimsel Araştırma Projeleri Koordinasyon Birimi AR-1535 no'lu projenin bir kısmıdır. Katkılarından dolayı teşekkür ederiz. 


\section{KAYNAKLAR}

[1] Öztürk, N., Basım, E., \& Basım, H. (2017). Tarımda Mikorizal Fungusların Etkinliği. Mantar Dergisi, 8 (1): 20-34.

[2] Özbucak, T. \& Kabul, D. (2019). Mikoriza Uygulanmış ve Uygulanmamış Domates Bitkisinde Farklı Fungusit Dozlarının Meyve Kalite Parametreleri Üzerindeki Etkilerinin Karşılaştırılması. Adü Ziraat Derg., 16(2):161-168.

[3] Kapoor, R., Chaudhary, V., Bhatnagar, A.K. (2007). Effects of arbuscular mycorrhiza and phosphorus application on artemisinin concentration in Artemisia annua L. Mycorrhiza, 17:581-587.

[4] Marin, M., Ybarra, M., Fe, A.,\& Garcia-Ferriz, L. (2002). Effect of arbuscular mycorrhizal fungi and pesticides on Cynara cardunculus growth. Agricultural and Food Science in Finland. 11: 245-251.

[5] Kabul, D. (2018). Domates (Solanum lycopersicum L.) Bitkisinde Mikorizanın Pestisit Direncinin İncelenmesi. Ordu Üniversitesi, Fen Bilimleri Enstitüsü, Yüksek Lisans Tezi, $112 \mathrm{~s}$.

[6] Zhu, X., Song, F.,\& Xu, H. (2010). Influence of arbuscular mycorrhiza on lipid peroxidation and antioxidant enzyme activity of maize plants under temperature stress. Mycorrhiza, 20:325-332.

[7] Pereira, J.A.P., Vieira, I.J.C., Freitas, M.S.M., Prins, C.L., Martins, M.A.,\& Rodrigues, R. (2016). Effects of arbuscular mycorrhizal fungi on Capsicum spp. J. Agri. Sci. 154,:828-849.

[8] Rafique, M. \& Ortaş, İ. (2018). Nutrient uptake-modification of different plant species in Mediterranean climate by arbuscular mycorrhizal fungi. Eur. J. Hortic. Sci. 83(2), 65-71.

[9] Korkmaz, A.A. (2005). Farklı Konukçu Bitki Ve Yetiştirme Ortamlarının Mikoriza Üretimi Ve Kalitesi Üzerine Etkileri. Çukurova Üniversitesi Fen Bilimleri Enstitüsü, Yüksek Lisans Tezi, 65s.

[10] Nersheim, O.N. (1993). Toxicity of pesticides. A series of the Pesticide Information Offici. Florida.

[11] Cordier, A.T., Gianinazzi, S.,\& Gianinazz-Pearson, V. (1996). Arbuscular mycorrhiza technology applied to micropropagated Prunus avium and to protection against Phytophthora cinnamomi. Agronomie, 16:676-688.

[12] Al-Karaki, G.N., (2000). Growth of mycorrhizal tomato and mineral acquisition under salt stress. Mycorrhiza, 10: 51-54.

[13] Hajiboland, R., Aliasgharzadeh, A., Laiegh, S.F.,\& Poschenrieder, C. (2010). Colonization with arbuscular mycorrhizal fungi improves salinity tolerance of tomato (Solanum lycopersicum L.) plants. Plant Soil, 331: 313-327.

[14] Abdel Latef, A.A., \& Chaoxing, H. (2011). Effects of arbucsular mycorrhizal fungi on growth, mineral nutrition, antioxidant enzymes activity and fruit yield of tomato grown under salinity stress. Sci.Hort., 127: 228-233.

[15] Çekiç, C. \& Yılmaz, E. (2011). Effect of arbuscular mycorrhiza and different doses of phosphor on vegetative and generative components of strawberries applied with different phosphor doses in soilless culture. African J of Agric Res, 6(20):4736-4739.

[16] Öztekin, G.B.\& Ece, M. (2014). Türkiye Tarımsal Araştırmalar Dergisi. Turk J Agric Res.1:35-42ISSN:2148 2306.

[17] Yalçın, E. (2018). Ekosistemlerde Yaprağın Ekolojik Fonksiyonları. Black Sea Journal of Engineering and Science 1(2): 68-82. 
[18] Ulukap1, K., Kurt, Z. \&Şener, S. (2020). The Effects of Mycorrhiza Application on Vegetative and Generative Growth in Pepper (Capsicum annuum L.) Plants under Water Deficiency Conditions. Turkish Journal of Agriculture - Food Science and Technology, 8(4): 927-931.

[19] Ortaş, İ.(1997). Mikoriza nedir? TÜBİTAK Bilim ve Teknik Dergisi, 351: 92-95.

[20] Erzurumlu, G.S. \& Kara, E.E. (2014). Mikoriza Konusunda Türkiye’de Yapılan Çalışmalar. Türk Bilimsel Derlemeler Dergisi 7 (2): 55-65.

[21] Abdulhadi, S. A. A. (2017). Tuzlu toprak koşullarında çerezlik kabakta arbusküler mikoriza fungi uygulamalarının fide gelişmesine etkisi (Doctoral dissertation, Selçuk Üniversitesi Fen Bilimleri Enstitüsü).

[22] Akkemik, Ü., (2007). Dendroloji (dendroloji, odunsu bitkiler ve bitki materyali dersleri için). İstanbul Üniv. Orman Fak. Orman Botaniği Anabilim dalı. İstanbul.

[23] Biçici, M. (2011). Bitki hastalık etmenleri ile biyolojik mücadelenin başarısını arttırmada mikoriza'nın rolü. Türk. biyo. müc. derg., 1, 2 (2): 139-174 ISSN 2146-0035.

[24] Altuntaş, Ö., Abak, K.\& Daşgan, H.Y. (2015). Serada Biber Yetiştiriciliğinde Arbusküler Mikorhizal Fungus Kullanımının Bitki Gelişimi ve Verime Etkileri. Selçuk Tar Bil Der., 2(2): 144-151.

[25] Küçükyumuk, Z., Gültekin, M. \&Erdal, İ. (2014). Vermikompost ve Mikorizanın Biber Bitkisinin Gelişimi ile Mineral Beslenmesi Üzerine Etkisi. Süleyman Demirel Üniversitesi Ziraat Fakültesi Dergisi 9 (1):51-58.

[26] Palta, Ş., Lermi Genç, A.\& Beki, R. (2016).The effect of different land uses on arbuscular mycorrhizal fungi in the northwestern Black Sea Region. Environ Monit Assess, 188: 350.

[27] Mohammad, A., Mitra, B. \& Khan, A. G. (2004). Effects of sheared-root inoculum of Glomus intraradices on wheat grown at different phosphorus levels in the field. Agriculture, ecosystems \& environment, 103(1): 245-249.

[28] Yılmaz, E. \& Gül, A. (2009). Topraksız Ortama Arbusküler Mikoriza Aşılamanın Patlıcan (Solanum melongena L.) Yetiştiriciliği Üzerine Etkileri. GOÜ. Ziraat Fakültesi Dergisi, 26(2): 55-61.

[29] Demir, S. (2004). Influence of Arbuscular Mycorrhiza on Some Physiological Growth Parameters of Pepper. Turk J Biol 28: 85-90 @ TÜBITTAK.

[30] Öztürk, İ., Tort, BN.B\&Tosun, N. (2006). Metalaxyl uygulamasının domatesin anatomik yapısı üzerine etkisi. Ankara Üniv.Ziraat Fak.Tarım Bilimleri Derg.,12(1),14-22.

[31] Li, Y., Johnson, D.A., Su, Y., Cui, J.\& Zhang, T. (2005).Specific leaf area and leaf dry matter content of plants growing in sand dunes. Botanical Bulletin of Academia Sinica, 46, 127-134.

[32] Ocak, E.\& Demir, S. (2012). Toprak verimliliği ve bitki gelişimindeki peyniraltı suyu ve Arbüsküler Mikorhizal fumgus (AMF) 'un önemi. Yyü Tar Bil Derg, 22(1):48-55. 


\begin{tabular}{|c|c|c|}
\hline & $\begin{array}{l}\text { BŞEÜ Fen Bilimleri Dergisi } \\
7(1), 529-543,2020\end{array}$ & $\begin{array}{r}\text { BSEU Journal of Science } \\
\text { DOI: } 10.35193 / \text { bseufbd. } 716195\end{array}$ \\
\hline 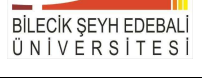 & & e-ISSN: 2458-7575 (http://dergipark.gov.tr/bseufbd) \\
\hline
\end{tabular}

Tablo 1. Bitkide kök uzunluğuna $(\mathrm{cm})$ ait tanıtıcı istatistik değerleri ve varyans analizi sonuçları

\begin{tabular}{|c|c|c|c|c|c|c|c|c|c|c|c|c|c|c|c|}
\hline \multirow[b]{2}{*}{$\begin{array}{l}\text { Fungusit } \\
\text { Dozu }\end{array}$} & \multicolumn{5}{|c|}{ Mikoriza Var $(n=3)$} & \multicolumn{5}{|c|}{ Mikoriza Yok $(n=3)$} & \multicolumn{5}{|c|}{ Genel $(n=6)$} \\
\hline & $\begin{array}{l}\text { Ortalama } \\
(\bar{X})\end{array}$ & $\begin{array}{l}\text { Std. } \\
\text { Hata } \\
\left(S_{\bar{X}}\right)\end{array}$ & $\begin{array}{l}\text { Std. } \\
\text { Sapma } \\
\left(S_{X}\right)\end{array}$ & Min. & Maks. & $\begin{array}{l}\text { Ortalama } \\
(\bar{X})\end{array}$ & $\begin{array}{l}\text { Std. } \\
\text { Hata } \\
\left(S_{\bar{X}}\right)\end{array}$ & $\begin{array}{l}\text { Std. } \\
\text { Sapma } \\
\left(S_{X}\right)\end{array}$ & Min. & Maks. & $\begin{array}{l}\text { Ortalam } \\
\mathbf{a} \\
(\bar{X})\end{array}$ & $\begin{array}{l}\text { Std. } \\
\text { Hata } \\
\left(S_{\bar{X}}\right)\end{array}$ & $\begin{array}{l}\text { Std. } \\
\text { Sapma } \\
\left(S_{X}\right)\end{array}$ & Min. & Maks. \\
\hline Kontrol & 36.000 & 2.179 & 3.775 & 32.500 & 40.000 & 32.333 & 2.587 & 4.481 & 29.500 & 37.500 & 34.167 & 1.721 & 4.215 & 29.500 & 40.000 \\
\hline $\mathrm{D} / 2$ & 34.667 & 3.492 & 6.048 & 30.000 & 41.500 & 33.833 & 3.245 & 5.620 & 29.000 & 40.000 & 34.250 & 2.140 & 5.242 & 29.000 & 41.500 \\
\hline $\mathrm{D}$ & 31.833 & 1.856 & 3.215 & 29.500 & 35.500 & 29.000 & 2.255 & 3.905 & 26.500 & 33.500 & 30.417 & 1.452 & 3.556 & 26.500 & 35.500 \\
\hline $\mathrm{D} * 2$ & 30.667 & 1.833 & 3.175 & 27.000 & 32.500 & 26.833 & 0.441 & 0.764 & 26.000 & 27.500 & 28.750 & 1.202 & 2.945 & 26.000 & 32.500 \\
\hline Genel $(n=12)$ & 33.292 & 1.222 & 4.234 & 27.000 & 41.500 & 30.500 & 1.307 & 4.528 & 26.000 & 40.000 & & & & & \\
\hline P-Değeri & \multicolumn{15}{|c|}{ Mikoriza:0.120 ; Doz:0.086 ; Mikoriza*Doz:0.919 } \\
\hline
\end{tabular}




\begin{tabular}{|c|c|c|}
\hline & $\begin{array}{l}\text { BŞEÜ Fen Bilimleri Dergisi } \\
7(1), 529-543,2020\end{array}$ & $\begin{array}{r}\text { BSEU Journal of Science } \\
\text { DOI: } 10.35193 / \text { bseufbd.716195 }\end{array}$ \\
\hline 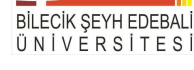 & & e-ISSN: 2458-7575 (http://dergipark.gov.tr/bseufbd) \\
\hline
\end{tabular}

Tablo 2. Bitkide gövde uzunluğuna $(\mathrm{cm})$ ait tanıtıcı istatistik değerleri ve varyans analizi sonuçlar

\begin{tabular}{|c|c|c|c|c|c|c|c|c|c|c|c|c|c|c|c|}
\hline \multirow[b]{2}{*}{$\begin{array}{l}\text { Fungusit } \\
\text { Dozu }\end{array}$} & \multicolumn{5}{|c|}{ Mikoriza Var $(n=3)$} & \multicolumn{5}{|c|}{ Mikoriza Yok $(n=3)$} & \multicolumn{5}{|c|}{ Genel (n=6) } \\
\hline & $\begin{array}{l}\text { Ortalama } \\
(\bar{X})\end{array}$ & $\begin{array}{l}\text { Std. } \\
\text { Hata } \\
\left(S_{\bar{X}}\right) \\
\end{array}$ & $\begin{array}{l}\text { Std. } \\
\text { Sapma } \\
\left(S_{X}\right) \\
\end{array}$ & Min. & Maks. & $\begin{array}{l}\text { Ortalama } \\
(\bar{X})\end{array}$ & $\begin{array}{l}\text { Std. } \\
\text { Hata } \\
\left(S_{\bar{X}}\right) \\
\end{array}$ & $\begin{array}{l}\text { Std. } \\
\text { Sapma } \\
\left(S_{X}\right) \\
\end{array}$ & Min. & Maks. & $\begin{array}{l}\text { Ortalama } \\
(\bar{X})\end{array}$ & $\begin{array}{l}\text { Std. } \\
\text { Hata } \\
\left(S_{\bar{X}}\right) \\
\end{array}$ & $\begin{array}{l}\text { Std. } \\
\text { Sapma } \\
\left(S_{X}\right) \\
\end{array}$ & Min. & Maks. \\
\hline Kontrol & 95.833 & 3.005 & 5.204 & 90.000 & 100.000 & 85.000 & 5.795 & 10.037 & 78.000 & 96.500 & $90.417 \mathrm{~B}$ & 3.793 & 9.292 & 78.000 & 100.000 \\
\hline $\mathrm{D} / 2$ & 97.500 & 1.258 & 2.179 & 95.000 & 99.000 & 101.333 & 0.441 & 0.764 & 100.500 & 102.000 & 99.417A & 1.044 & 2.558 & 95.000 & 102.000 \\
\hline $\mathrm{D}$ & 97.667 & 1.641 & 2.843 & 94.500 & 100.000 & 91.333 & 2.028 & 3.512 & 88.000 & 95.000 & $94.500 \mathrm{AB}$ & 1.835 & 4.494 & 88.000 & 100.000 \\
\hline $\mathrm{D} * 2$ & 89.167 & 2.774 & 4.805 & 84.000 & 93.500 & 87.000 & 3.617 & 6.265 & 81.000 & 93.500 & $88.083 \mathrm{~B}$ & 2.095 & 5.132 & 81.000 & 93.500 \\
\hline $\begin{array}{l}\text { Genel } \\
(n=12)\end{array}$ & 95.042 & 1.431 & 4.956 & 84.000 & 100.000 & 91.167 & 2.434 & 8.432 & 78.000 & 102.000 & & & & & \\
\hline P-Değeri & \multicolumn{15}{|c|}{ Mikoriza:0.086; Doz:0.009**; Mikoriza*Doz:0.132 } \\
\hline
\end{tabular}

Ortak harfi olmayan doz ortalamaları arasındaki farklılık istatistik olarak önemlidir $(\mathrm{p}<0.05)$ 


\begin{tabular}{|c|c|c|}
\hline & $\begin{array}{l}\text { BŞEÜ Fen Bilimleri Dergisi } \\
7(1), 529-543,2020\end{array}$ & $\begin{array}{r}\text { BSEU Journal of Science } \\
\text { DOI: } 10.35193 / \text { bseufbd.716195 }\end{array}$ \\
\hline $\begin{array}{l}\text { BDLECECK SEYH EDEBALL } \\
\text { UN IVERSITES }\end{array}$ & & e-ISSN: 2458-7575 (http://dergipark.gov.tr/bseufbd) \\
\hline
\end{tabular}

Tablo 3. Yaprak yaş ağırlığına (g) ait tanıtıcı istatistik değerleri ve varyans analizi sonuçları

\begin{tabular}{|c|c|c|c|c|c|c|c|c|c|c|c|c|c|c|c|}
\hline \multirow[b]{2}{*}{$\begin{array}{l}\text { Fungusit } \\
\text { Dozu }\end{array}$} & \multicolumn{5}{|c|}{ Mikoriza Var $(n=3)$} & \multicolumn{5}{|c|}{ Mikoriza Yok (n=3) } & \multicolumn{5}{|c|}{ Genel $(n=6)$} \\
\hline & $\begin{array}{l}\text { Ortalama } \\
(\bar{X})\end{array}$ & $\begin{array}{l}\text { Std. Hata } \\
\left(\boldsymbol{S}_{\bar{X}}\right)\end{array}$ & $\begin{array}{l}\text { Std. } \\
\text { Sapma } \\
\left(S_{X}\right)\end{array}$ & Min. & Maks. & $\begin{array}{l}\text { Ortalama } \\
(\bar{X})\end{array}$ & $\begin{array}{l}\text { Std. Hata } \\
\left(S_{\bar{X}}\right)\end{array}$ & $\begin{array}{l}\text { Std. Sapma } \\
\left(S_{X}\right)\end{array}$ & Min. & Maks. & $\begin{array}{l}\text { Ortalama } \\
(\bar{X})\end{array}$ & $\begin{array}{l}\text { Std. } \\
\text { Hata } \\
\left(S_{\bar{X}}\right)\end{array}$ & $\begin{array}{l}\text { Std. } \\
\text { Sapma } \\
\left(S_{X}\right)\end{array}$ & Min. & Maks. \\
\hline Kontrol & 1.996 & 0.165 & 0.286 & 1.669 & 2.204 & 1.807 & 0.236 & 0.408 & 1.426 & 2.238 & 1.902 & 0.135 & 0.332 & 1.426 & 2.238 \\
\hline $\mathrm{D} / 2$ & 1.992 & 0.160 & 0.277 & 1.693 & 2.238 & 1.725 & 0.198 & 0.343 & 1.472 & 2.115 & 1.858 & 0.129 & 0.315 & 1.472 & 2.238 \\
\hline D & 1.987 & 0.221 & 0.382 & 1.547 & 2.232 & 1.642 & 0.125 & 0.217 & 1.443 & 1.873 & 1.814 & 0.137 & 0.336 & 1.443 & 2.232 \\
\hline $\mathrm{D} * 2$ & 2.060 & 0.173 & 0.300 & 1.715 & 2.261 & 1.737 & 0.265 & 0.459 & 1.207 & 2.003 & 1.898 & 0.159 & 0.389 & 1.207 & 2.261 \\
\hline $\begin{array}{l}\text { Genel } \\
(\mathrm{n}=12)\end{array}$ & 2.009 & 0.078 & 0.270 & 1.547 & 2.261 & 1.728 & 0.092 & 0.320 & 1.207 & 2.238 & & & & & \\
\hline P-Değeri & \multicolumn{15}{|c|}{ Mikoriza:0.061; Doz:0.967; Mikoriza*Doz:0.979 } \\
\hline
\end{tabular}




\begin{tabular}{|c|c|c|}
\hline & $\begin{array}{l}\text { BŞEÜ Fen Bilimleri Dergisi } \\
7(1), 529-543,2020\end{array}$ & $\begin{array}{r}\text { BSEU Journal of Science } \\
\text { DOI: } 10.35193 / \text { bseufbd. } 716195\end{array}$ \\
\hline & & e-ISSN: 2458-7575 (http://dergipark.gov.tr/bseufbd) \\
\hline
\end{tabular}

Tablo 4. Yaprak kuru ağırlı̆̆ına (g) ait tanıtıı istatistik değerleri ve varyans analizi sonuçlar

\begin{tabular}{|c|c|c|c|c|c|c|c|c|c|c|c|c|c|c|c|}
\hline \multirow[b]{2}{*}{$\begin{array}{l}\text { Fungusit } \\
\text { Dozu }\end{array}$} & \multicolumn{5}{|c|}{ Mikoriza Var $(n=3)$} & \multicolumn{5}{|c|}{ Mikoriza Yok $(n=3)$} & \multicolumn{5}{|c|}{ Genel $(n=6)$} \\
\hline & $\begin{array}{l}\text { Ortalama } \\
(\bar{X})\end{array}$ & $\begin{array}{l}\text { Std. Hata } \\
\left(S_{\bar{X}}\right)\end{array}$ & $\begin{array}{l}\text { Std. Sapma } \\
\left(S_{X}\right)\end{array}$ & Min. & Maks. & $\begin{array}{l}\text { Ortalama } \\
(\bar{X})\end{array}$ & $\begin{array}{l}\text { Std. Hata } \\
\left(S_{\bar{X}}\right)\end{array}$ & $\begin{array}{l}\text { Std. } \\
\text { Sapma } \\
\left(S_{X}\right)\end{array}$ & Min. & Maks. & $\begin{array}{l}\text { Ortalama } \\
(\bar{X})\end{array}$ & $\begin{array}{l}\text { Std. Hata } \\
\left(S_{\bar{X}}\right)\end{array}$ & $\begin{array}{l}\text { Std. } \\
\text { Sapma } \\
\left(S_{X}\right)\end{array}$ & Min. & Maks. \\
\hline Kontrol & 0.422 & 0.054 & 0.093 & 0.322 & 0.506 & 0.390 & 0.077 & 0.133 & 0.290 & 0.541 & 0.406 & 0.042 & 0.104 & 0.290 & 0.541 \\
\hline $\mathrm{D} / 2$ & 0.448 & 0.044 & 0.077 & 0.367 & 0.521 & 0.345 & 0.038 & 0.066 & 0.300 & 0.421 & 0.397 & 0.035 & 0.086 & 0.300 & 0.521 \\
\hline $\mathrm{D}$ & 0.450 & 0.033 & 0.058 & 0.416 & 0.516 & 0.327 & 0.030 & 0.052 & 0.279 & 0.383 & 0.388 & 0.034 & 0.083 & 0.279 & 0.516 \\
\hline $\mathrm{D} * 2$ & 0.413 & 0.029 & 0.051 & 0.356 & 0.454 & 0.333 & 0.057 & 0.098 & 0.220 & 0.399 & 0.373 & 0.034 & 0.083 & 0.220 & 0.454 \\
\hline $\begin{array}{l}\text { Genel } \\
(n=12)\end{array}$ & 0.433 & 0.018 & 0.063 & 0.322 & 0.521 & 0.349 & 0.024 & 0.083 & 0.220 & 0.541 & & & & & \\
\hline P-Değeri & \multicolumn{15}{|c|}{ Mikoriza:0.024*; Doz:0.916 ; Mikoriza*Doz:0.800 } \\
\hline
\end{tabular}




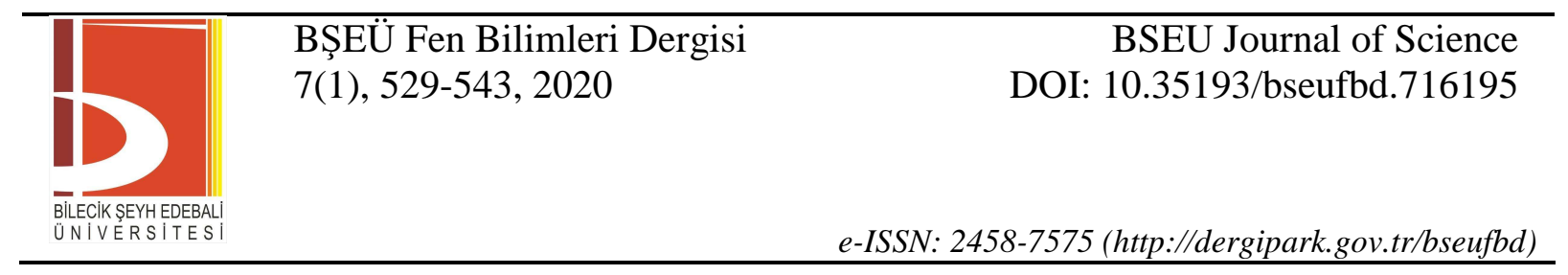

Tablo 5. Spesifik yaprak alanına $\left(\mathrm{dm}^{2} / \mathrm{g}\right)$ ait tanıtııı istatistik değerleri ve varyans analizi sonuçları

\begin{tabular}{|c|c|c|c|c|c|c|c|c|c|c|c|c|c|c|c|}
\hline \multirow[b]{2}{*}{ Fungusit Dozu } & \multicolumn{5}{|c|}{ Mikoriza Var $(n=3)$} & \multicolumn{5}{|c|}{ Mikoriza Yok (n=3) } & \multicolumn{5}{|c|}{ Genel $(n=6)$} \\
\hline & $\begin{array}{l}\text { Ortalama } \\
(\bar{X})\end{array}$ & $\begin{array}{l}\text { Std. Hata } \\
\left(S_{\bar{X}}\right)\end{array}$ & $\begin{array}{l}\text { Std. } \\
\text { Sapma } \\
\left(S_{X}\right)\end{array}$ & Min. & Maks. & $\begin{array}{l}\text { Ortalam } \\
\mathbf{a} \\
(\bar{X})\end{array}$ & $\begin{array}{l}\text { Std. Hata } \\
\left(S_{\bar{X}}\right)\end{array}$ & $\begin{array}{l}\text { Std. } \\
\text { Sapma } \\
\left(S_{X}\right)\end{array}$ & Min. & Maks. & $\begin{array}{l}\text { Ortalama } \\
(\bar{X})\end{array}$ & $\begin{array}{l}\text { Std. } \\
\text { Hata } \\
\left(S_{\bar{X}}\right)\end{array}$ & $\begin{array}{l}\text { Std. } \\
\text { Sapma } \\
\left(S_{X}\right)\end{array}$ & Min. & Maks. \\
\hline Kontrol & 0.940 & 0.062 & 0.108 & 0.820 & 1.030 & 0.827 & 0.165 & 0.285 & 0.550 & 1.120 & 0.883 & 0.083 & 0.203 & 0.550 & 1.120 \\
\hline $\mathrm{D} / 2$ & 0.897 & 0.038 & 0.065 & 0.830 & 0.960 & 0.850 & 0.050 & 0.087 & 0.750 & 0.900 & 0.873 & 0.030 & 0.073 & 0.750 & 0.960 \\
\hline D & 0.963 & 0.087 & 0.150 & 0.790 & 1.050 & 1.000 & 0.145 & 0.251 & 0.850 & 1.290 & 0.982 & 0.076 & 0.186 & 0.790 & 1.290 \\
\hline $\mathrm{D} * 2$ & 0.880 & 0.121 & 0.209 & 0.640 & 1.020 & 1.093 & 0.089 & 0.154 & 0.990 & 1.270 & 0.987 & 0.082 & 0.201 & 0.640 & 1.270 \\
\hline Genel $(n=12)$ & 0.920 & 0.037 & 0.127 & 0.640 & 1.050 & 0.943 & 0.061 & 0.212 & 0.550 & 1.290 & & & & & \\
\hline P-Değeri & \multicolumn{15}{|c|}{ Mikoriza:0.763; Doz:0.566 ; Mikoriza*Doz:0.449 } \\
\hline
\end{tabular}




\begin{tabular}{|c|c|c|}
\hline & $\begin{array}{l}\text { BŞEÜ Fen Bilimleri Dergisi } \\
7(1), 529-543,2020\end{array}$ & $\begin{array}{r}\text { BSEU Journal of Science } \\
\text { DOI: } 10.35193 / \text { bseufbd.716195 }\end{array}$ \\
\hline $\begin{array}{l}\text { BDLECECK SEYH EDEBALL } \\
\text { UN IVERSITES }\end{array}$ & & e-ISSN: 2458-7575 (http://dergipark.gov.tr/bseufbd) \\
\hline
\end{tabular}

Tablo 6. Yaprak Kütle Ağırlığı $\left(\mathrm{g} / \mathrm{dm}^{2}\right)$ ait tanıtıcı istatistik değerleri ve varyans analizi sonuçları

\begin{tabular}{|c|c|c|c|c|c|c|c|c|c|c|c|c|c|c|c|}
\hline \multirow[b]{2}{*}{ Fungusit Dozu } & \multicolumn{5}{|c|}{ Mikoriza Var $(n=3)$} & \multicolumn{5}{|c|}{ Mikoriza Yok $(n=3)$} & \multicolumn{5}{|c|}{ Genel $(n=6)$} \\
\hline & $\begin{array}{l}\text { Ortalama } \\
(\bar{X})\end{array}$ & $\begin{array}{l}\text { Std. } \\
\text { Hata } \\
\left(S_{\bar{X}}\right)\end{array}$ & $\begin{array}{l}\text { Std. } \\
\text { Sapma } \\
\left(S_{X}\right)\end{array}$ & & $\begin{array}{l}\text { Ortala } \\
\text { ma } \\
(\bar{X})\end{array}$ & $\begin{array}{l}\text { Std. Hata } \\
\left(\boldsymbol{S}_{\bar{X}}\right)\end{array}$ & $\begin{array}{l}\text { Std. } \\
\text { Sapma } \\
\left(S_{X}\right)\end{array}$ & & $\begin{array}{l}\text { Ortalam } \\
\text { a } \\
(\bar{X})\end{array}$ & $\begin{array}{l}\text { Std. Hata } \\
\left(S_{\bar{X}}\right)\end{array}$ & $\begin{array}{l}\text { Std. } \\
\text { Sapma } \\
\left(S_{X}\right)\end{array}$ & & $\begin{array}{l}\text { Ortalam } \\
\mathbf{a} \\
(\bar{X})\end{array}$ & $\begin{array}{l}\text { Std. } \\
\text { Hata } \\
\left(S_{\bar{X}}\right)\end{array}$ & $\begin{array}{l}\text { Std. } \\
\text { Sapma } \\
\left(S_{X}\right)\end{array}$ \\
\hline Kontrol & 1.077 & 0.074 & 0.129 & 0.970 & 1.220 & 1.310 & 0.269 & 0.465 & 0.890 & 1.810 & 1.193 & 0.135 & 0.331 & 0.890 & 1.810 \\
\hline $\mathrm{D} / 2$ & 1.120 & 0.049 & 0.085 & 1.040 & 1.210 & 1.183 & 0.073 & 0.127 & 1.110 & 1.330 & 1.152 & 0.042 & 0.103 & 1.040 & 1.330 \\
\hline D & 1.057 & 0.107 & 0.185 & 0.950 & 1.270 & 1.033 & 0.132 & 0.228 & 0.770 & 1.170 & 1.045 & 0.076 & 0.186 & 0.770 & 1.270 \\
\hline $\mathrm{D} * 2$ & 1.190 & 0.190 & 0.330 & 0.980 & 1.570 & 0.927 & 0.069 & 0.119 & 0.790 & 1.010 & 1.058 & 0.108 & 0.265 & 0.790 & 1.570 \\
\hline Genel (n=12) & 1.111 & 0.053 & 0.182 & 0.950 & 1.570 & 1.113 & 0.080 & 0.278 & 0.770 & 1.810 & & & & & \\
\hline P-Değeri & \multicolumn{15}{|c|}{ Mikoriza:0.980 ; Doz:0.665 ; Mikoriza*Doz:0.377 } \\
\hline
\end{tabular}

